to have its third director-George W. Beadle, the retiring president of the University of Chicago. (His predecessors were Dr Roy E. Ritts and Sir John Eccles.) The AMA has also decided to move the institute to a new site on the campus of the University of Chicago. Unless the BMA decides to spend a good deal more on research, however, it is unlikely to be troubled by problems such as these.

\section{Doctors' Complaints}

THE career structure of the medical profession in Britain is an important stimulus of the emigration of doctors and an effective deterrent to their return. This is one of the conclusions reached by an interview board sent by the Ministry of Health to the United States and Canada last Oetober and which has now reported its findings. (British Medical Journal, i, $45 ; 1968$.)

Between 1962 and 1964 the rate of emigration of British doctors to all countries was about 300 a yearmore than one-sixth of the annual output of British medical schools in those years. This rate of emigration, which there is no reason to suppose will have diminished in subsequent years, was the goad to the board's departure. Having advertised its coming in various medical journals, it was able to interview 135 out of the 200 doctors who applied to it, with the purpose both of finding them jobs in Britain and of ascertaining why they had left and what impediments they saw to their return. Fifty of the doctors whom the board interviewed have already been offered, and have accepted, appointments in Britain and it is expected that more will do so.

The board discovered a fairly consistent picture of dissatisfaction with the National Health Service and its doings. General practitioners who in Britain had aspired to a specialist career gave as their reason for emigrating the lack of hospital facilities for doing major surgery and other specialized practice, and the waiting period for senior posts after the appropriate higher qualifications had been gained. Other reasons for emigrating were the paucity of senior academic posts in the United Kingdom and the relative scarcity of research funds. To the board's regret, it found that an emigrant's decision to leave was not always a purely personal one: "evidence of British consultants and professors advising and encouraging trainees to emigrate because of the uncertainty of their prospects and the rigidity of the National Health Service and academic structure in the United Kingdom was unfortunately forthcoming".

For those who wish to return to the United Kingdom, the most formidable obstacle is the insistence by the National Health Service that candidates attend an interview. If unsuccessful the candidate is left with his travelling expenses to pay, and if successful he is faced with removal costs of his dependants and effects as well. In this instance the board was empowered to reimburse such costs, which may account for much of its success in attracting doctors back. Other impedi. ments to a return are the lack of information about jobs, the hostile attitude of the North American press, and its British element in particular, towards the National Health Service, and the lack of any accepted equivalence bctween the higher qualifications awarded in North America and in Britain.
One reason for the board's success may have been that it was less scrupulous in selecting candidates for interview than other interview boards have been. It recommends that the obstacles to return should be reduced, and that to diminish the rate of emigration in future the arrangements for career guidance of trainees should be improved and that more opportunities should be created for academic careers. The Minister of Health is now studying these recommendations.

The loss of 300 doctors a year is indeed serious, but should be seen in proportion to the numbers Britain gains from other countries. Last year almost 2,000 doctors from the Commonwealth alone applied to enter Britain. In 1965, the most recent year for which figures are available, there were 6,000 doctors working in National Health hospitals who had been born abroad-about 30 per cent of the total. Of general practitioners 2,600 , or 12 per cent of the total, were born abroad. If every doctor were to practise in the country of his birth, Britain would not be the gainer. But this is not to decry any efforts that the ministry may now make to encourage the return of expatriates, and to allay the discontent of those who would follow them.

\section{More on Asbestosis}

THAT there are risks associated with asbestos is not now disputed. A review of the problem as it occurs in Britain has just been published as a memorandum by the Advisory Panel on Problems Arising from the Use of Asbestos (HMSO, 3s. 9d.). The advisory panel, set up in 1965 by HM Factory Inspectorate, is responsible for considering the use of asbestos in relation to the health of those directly or indirectly exposed to asbestos in their occupations. Over the whole country the panel estimates that about 20,000 persons are exposed to asbestos in the use or handling of the fibres. The figure is probably higher than this; people can easily be put at risk by working near to where asbestos is handled. The present Asbestos Industry Regulations, 1931, are applied to some 300 registered factories, but the report says that there are many other factories which use asbestos products and which do not come within the regulations. The Ministry of Labour is at present drawing up new regulations to cover a wider range of factories.

It was in the 1920 s that it was first elearly recognized that asbestosis, a fibrotic condition of the lungs, is caused by occupational exposure to asbestos. Within a few years it was suggested that the disease might be complicated by the development of carcinoma of the lung, but an association was not generally accepted until the $1950 \mathrm{~s}$. Recently, there has been concern over the occurrence of mesothelial tumours of the pleura or peritoneum which appear to be causally related to asbestos exposure in many cases. Since 1966 mesothelioma has been a scheduled industrial discase.

The advisory panel concludes that there is an increasing incidence of asbestosis in the country. The most likely explanation for this increase is the greater use of asbestos and the greater numbers of people employed in the industry over the past 20 years. But the panel says that "there is no evidence that the overall attack rate has decreased in the industry over this period, although it has in some textile mills in which the dust conditions have been greatly 